\title{
The Okavango Delta: the value of tourism
}

\author{
G Mmopelwa
}

Harry Oppenheimer Okavango Research Centre, University of Botswana

JN Blignaut

Department of Economics, University of Pretoria

\begin{abstract}
In Botswana, tourism is the second most important economic activity after diamond mining and trading. The Okavango Delta in northern Botswana is the largest single tourist centre in the country. This study estimates the total economic value of tourism in the Okavango Delta and compares this value to that of other sectors in the economy of Botswana. The results are compared to results of similar studies for tourist destinations elsewhere in the world, and the policy implications of the findings are highlighted. The study uses secondary data to estimate the direct consumptive and non-consumptive use value, and a survey among tourists to determine the existence value of the Okavango Delta.
\end{abstract}

JEL O13, Q20

1

\section{Introduction}

Botswana is a semi-arid yet biodiversity-rich land-locked country in southern Africa, with a surface area of 582000 square kilometres. The Okavango Delta (hereafter called the Delta) ecosystem in northwest Botswana is one of the sources of this biological diversity. The Delta, which is also the largest Ramsar site in the world, is a unique wetland ecosystem that provides habitats for countless species of animals and plants (Masundire et al., 1998; Monna, 1999).

Tourism has become Botswana's second most important economic activity after diamond mining and is currently the fastest growing sector in the economy. This is evident from the fact that its contribution to GDP has increased from 2.5 per cent in 1996/97 to 3.6 per cent in $2000 / 2001$ and 3.8 per cent in 2001/2002 (Republic of Botswana 2004). The Delta, in turn, is the largest single tourism centre in the country (Republic of Botswana 2003). Tourism in the Delta has also led to the development of community-based tourism projects that have created job opportunities for the rural population (Mbaiwa, 2002). The Delta's main tourism attractions relate to its complex mosaic of dryland, island fringe and wetland habitat and associated wildlife including big game, birds, fish, reptiles and amphibians (Masundire et al., 1998; Ashton et al. 2003). The Delta provides appealing scenery and novel recreational activities, which include canoe rides, site seeing, motorboat cruises and game fishing (Rothert, 1997; Mbaiwa, 2002; Gumbricht et al., 2004).

In light of the significance of the Delta's contribution to the economy of Botswana, it is necessary to determine the economic value of tourism in the Delta for the following reasons: first, Botswana's mineral-based economy may not necessarily be sustainable in the long term, and tourism is said to be the best option for economic diversification (see Republic of Botswana, 2003), hence, the need to determine the economic value of what could be the mainstay of Botswana's economy in the future. Secondly, it is common knowledge that wetlands are under heavy pressure of conversion and over-exploitation, primarily because their 
economic value is generally underappreciated worldwide (Turner, Pearce \& Bateman, 2000). This lack of economic appreciation is due to the fact that they are generally considered to be wastelands, their products are not marketed and they are exploited on open-access basis (Barbier, Acreman \& Knower, 1997; Silvius, Oneka \& Verhagen, 2000; Turner et al., 2000). If no effort is made to quantify the economic value of wetlands, the result is an implicit assumption that their value is zero (Loomis et al., 2000; Howarth \& Farber, 2002), which leads to their subsequent conversion (Turner et al., 2000). The Delta is not an exception in the list of wetlands threatened by water abstraction (Ashton et al., 2003).

The low perceived value of wetlands has however begun to prompt calculation of their economic value as basis for conservation (Turpie, 2004). Economic valuation provides decision makers with information vital for making land-use decisions as well as for formulating and operating sustainable strategies for the management of natural resources (Loomis et al., 2000; Turner et al., 2000). The same strategy could be applied to the Delta, and so this study attempts to calculate the economic value thereof. The next section will provide a conceptual background to the concept of the economic valuation of wetlands; thereafter the existing local and international literature on the matter will be reviewed. Section 4 discusses the methodology followed in this study, which is followed by a discussion of the results in Section 5 and the conclusion in Section 6.

\section{2}

\section{Conceptual background}

Ecosystems such as wetlands are very complex and provide a variety of ecosystem goods and services such as flood control and water purification, and act as a sponge that releases water slowly for use during dry periods. Wetlands also provide the opportunity for fishing, bird watching and a variety of other recreation activities (Loomis et al., 2000). Some of these goods and services can be valued using market prices, but others cannot, because they are not traded in the market, For these goods non-market techniques have to be used (Pearce \& Moran, 1994; Prato, 1998). Both the marketed and the non-marketed values together form the total economic value (TEV) of a resource. In addition to distinguishing between marketed and non-marketed values, the TEV framework of environmental resources distinguishes between use and non-use values (see Figure 1) (Munasinghe, 1992; Hanley \& Splash, 1993; Pearce \& Moran, 1994; Kahn, 1997).

Use values can be further subdivided into direct and indirect use values. Direct use values, which can be divided into consumptive use (e.g. biomass harvesting; hunting; etc.) and nonconsumptive use (e.g. game viewing), are conceptually straightforward but not necessarily easy to measure in terms of money. Indirect use values correspond closely to socalled 'ecological functions' (e.g. watershed protection, carbon sequestration, nutrient recycling) and are even more difficult to quantify. Option values are an expression of preference, willingness-to-pay for the preservation of an environment against the probability that the individual will make use of it later (Pearce \& Turner, 1990: 130).

Non-use values, on the other hand, are intangible values that people derive from preservation of the environmental assets such as wetlands (Oglethorpe \& Miliadou, 2000). Two categories of non-use values are recognised, namely existence and bequest values. An existence value is value attached to knowing that an environmental asset exists even though the value attributer may not be interested in consuming that resource (Barbier et al., 1997; Oglethorpe \& Miliadou, 2000; Turner et al., 2000). According to Chopra (1993), existence value is related to the extent to which the loss of a resource is irreversible and irreplaceable. A bequest value is the value that an individual derives from ensuring that the resources will be available in the future (Oglethorpe \& Miliadou, 2000; Turner et al., 2000). 
Figure 1

Value of an ecosystem

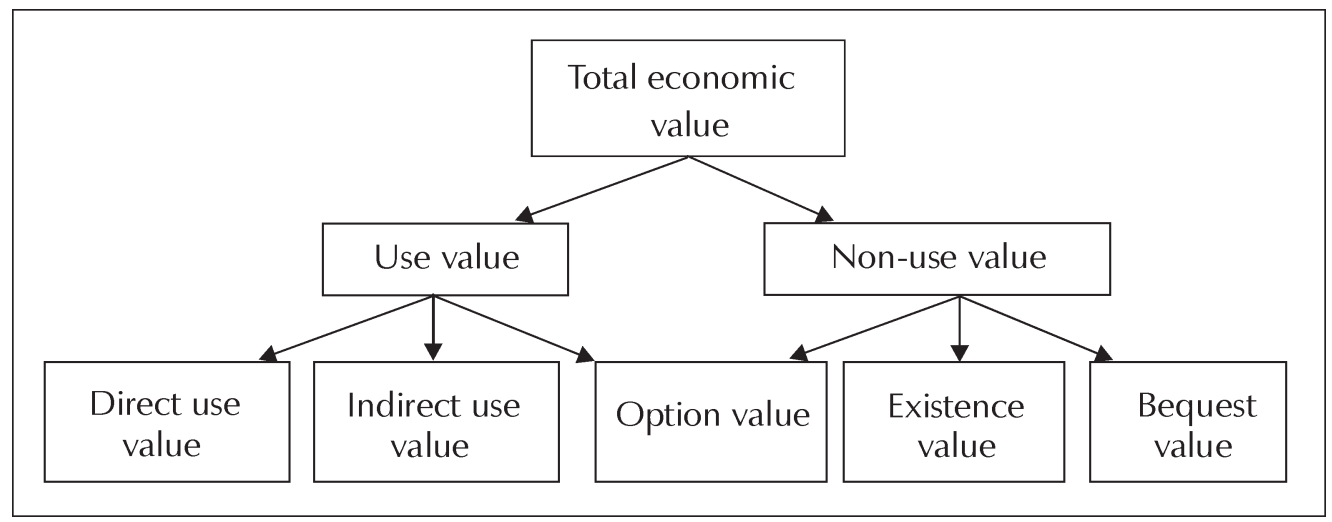

Source: Adapted from Turner et al., 1994

Literature indicates (as discussed below) that the value of tourism and recreation has been estimated mostly using the travel cost method (TCM) and the contingent valuation method (CVM). The TCM assumes that expenditure incurred to a recreation site can be used as a proxy for price of access to that side (Kahn 1997). Data derived from travel costs and visitations can be used to construct a demand curve for visits. The rate of visits expresses the amount of recreational experience that has been bought (Navruud \& Mungatana, 1994). The area under the demand curve is known as the consumer surplus and is defined as the difference between total willingness to pay and total actual expenditure (Kahn, 1997; Tietenberg, 2000; Perman et al., 2003). The consumer surplus is the value of the recreation experience (Navruud \& Mungatana, 1994). In the context of park pricing, the consumer surplus reflects the benefit forgone for not charging higher entry fees in game parks (Krug, Suich \& Haimboden, 2002).

The CVM is a direct and stated preference economic valuation technique commonly applied in determination of non-use values (Sutherland \& Walsh, 1985; Pearce \& Turner, 1990; Bateman \& Langford, 1997; Folmer, Gabel \& Opschoor, 1997; Pate \& Loomis, 1997; Kahn, 1997; Blomquist \& Whitehead, 1998; Oglethorpe \& Miliadou, 2000; Bateman et al., 2002; Carson, 2004). A CVM survey asks a sample of the population about their willingness to pay for the conservation of an amenity or willingness to accept compensation for the loss of an amenity, both techniques using a hypothetical scenario (Kahn, 1997; Perman et al., 2003). The willingness to pay is investigated by face-to-face interviews, mail surveys or telephone surveys using open-ended questions, closed or dichotomous (referendum) questions or a payment card (Hanley \& Splash, 1993; Bateman et al., 2002; Perman, et al. 2003). While the use of CVM is widespread, it is associated with some biases such as strategic, design and hypothetical biases (see Pearce \& Turner, 1990; Oglethorpe \& Miliodou, 2000; Perman et al., 2003; Venkatachalam, 2004 for a discussion of the different biases). However, most of these biases can be avoided by designing good surveys backed up by extensive pre-testing (Perman et al., 2003).

Before embarking on an analysis of this study's research method and results, a review of both local and international literature pertaining to the valuation of the Delta is needed.

\section{3}

\section{Literature review}

Past research on tourism in the Delta has covered areas such as the socio-economic and environmental impact of tourism development (e.g. Mbaiwa, 2002), and the economic, social 
and environmental sustainability of enclave tourism and its economic impact on the Delta (e.g. Mbaiwa, 2005). Other research aims to estimate the economic values of individual resources that may be directly or indirectly related to tourism. These studies include the economic analysis of craft-based resources (e.g. Terry, 1999), financial and economic viability of commercial fishing in Shakawe (e.g. Mmopelwa, Segametse \& Mosepele, 2005), and the willingness of households to pay for improved water supply and quality in the village of Maun (e.g. Mmopelwa et al., 2005). Barnes, Cannon and Morrison (2001) describe an economic analysis of various land use options (including commercial wildlife viewing). Barnes (1998) applies the CVM as part of a larger study on determining direct use values in the wildlife sector in Botswana. The CVM determines the proportion of tourists' expenditures consisting of the consumer surplus, the willingness of tourists to contribute to a conservation fund and the willingness of tourists to pay increased fees to enter the park. The study reveals that visitors have a consumer surplus ranging between 17 and 20 percent of the total trip costs, and are willing to donate money for the conservation of wildlife resource of Botswana. No comprehensive study determining the TEV of tourism for the Delta has been done yet. This study fills this gap.

Elsewhere, the demand for recreation has also been a subject of many studies. In most of these studies the results from the application of the TCV and the CVM have led to recommendations about policy implications in management of natural resources. For example, Seenpracwong (2000) finds that international and domestic visitors to a tourist destination of Phi Phi in Thailand have a high consumer surplus and an average willingness to pay for increased park fees and concludes that the results should serve as strong justification for greater government expenditure on coastal resource management. In a survey in the Seychelles Marine national park, Mathieu, Langford and Kenyon (2000) find that tourists are willing to pay increased park fees (consumer surplus) of up to US\$12.20, which could be used for the management of the park. Similarly, in Etosha national park in Namibia, a study on tourist willingness to pay for increased park fees (Barnes, Schier \& Van Rooy, 1997) reveals that local and foreign visitors have a consumer surplus of $\mathrm{N} \$ 362$ (US\$81.68) and $\mathrm{N} \$ 627$ (US\$141.47) per tourist, respectively. In addition, the average tourist is willing to pay $\mathrm{N} \$ 104$ (US\$23.47) into a wildlife conservation fund. In one of Africa's most popular tourist destinations, the only waterfowl habitat protected under the Ramsar convention, namely the Nakuru National Park in Kenya, Navruud and Mungatana (1994) find that both the TCM and the CVM reveal that the Lake has an economic potential far greater than its realised economic earnings.

While the TCM and the CVM have been widely applied in many studies, other approaches of valuation have also been used to inform policy. For instance, the contingent ranking method, a variant of the CVM, is applied by Isangkura (2000) to measure the recreational value of three recreational areas, Doi Inthanon national park, Suthep-Pui national park and Mae Sa Waterfall in northern Thailand. The conclusion of this study is that entry fees for Doi Inthanon National park should be increased by USD $\$ 0.12$ per person to increase park revenues from US\$125000 per year to US $\$ 1$ million. In the Cape Floristic Region in South Africa, Turpie, Heydenrych \& Lamberth (2003) estimate various economic values (consumptive use value, non-consumptive use value of tourism, indirect use value, and option and existence values). The value of tourism is estimated from published information on tourist numbers and expenditure, and expenditure due to nature-based tourism is estimated on the basis of a questionnaire survey. The study finds that the overall contribution of nature-based tourism is R7 443 million (US $\$ 1063$ million) or 7.2 per cent of Gross Geographic Product.

Literature on the estimation of non-use values has also provided the necessary valuation information for conservation and sustainable utilisation of natural resources such as wetlands. An application of the CVM in the determination of non-use values for Lake Kerkin in northern Greece reveals that the Lake is highly valued by 
respondents who are willing to pay up to $£ 15.24$ / annum (US\$8.87) for the conservation of this lake (Oglethorpe Miliodou, 2000). The willingness to pay is based on the fact that the lake is under threat of overfishing and increasing recreational pressure. Based on these findings, the study recommends that the Lake not be converted, but be strictly protected from all kinds of threats. Similarly, Bateman and Langford (1997) find that onsite visitors have deep concern for the protection of the Norfolk Broads in England (a site of recognized national and international significance) from the threat of saline flooding. The visitors are willing to pay extra taxes for the prevention of flooding.

From these studies it is evident that there are many widespread cases where the economic values exceed the financial returns of a recreation or conservation area. The economic value of the Delta will now be studied.

\section{4}

\section{Methodology}

The methodology of this study aims to determine the direct consumptive and nonconsumptive use values of tourism as well as the non-use values held by tourists who visited the Okavango Delta in 2003.

\subsection{Direct consumptive use values}

Direct consumptive use value is that of hunting wildlife. Data on the number of game hunts are obtained from hunting quotas for citizen hunting areas, community managed wildlife areas and concession areas for 2003. The hunting quotas are compiled by the Department of Wildlife and National Parks. In computing the consumptive use value, citizen and noncitizen prices of licences for different animal species are used as a proxy for the market prices of animals. License prices for citizens are lower than license prices for non-citizens. The value of hunting is determined by multiplying the number of animals hunted by their respective prices.

\subsection{Direct non-consumptive use values}

Secondary data is used to estimate direct nonconsumptive use values of tourism in the Moremi game reserve in the Delta. Data are obtained from a report of the Northern Parks and Reserve Visitor Statistics for 2003, which is periodically compiled by the Department of Wildlife and National Parks.

The value of tourism associated with nonconsumptive use values includes travel costs by tourists using air or road transport, revenues from accommodation (camping fees), entry fees, vehicle fees, boat fees, aircraft landing fees and other fees (such as filming and permit renewals for guides). While the cost of international travel is a very significant component of the nonconsumptive use value of tourism, there is often a difficulty in estimating this value due to multiple visits. The difficulty arises because the value of travel expenditure to a particular destination cannot be isolated from other destinations that are visited. To resolve this problem, only air travel costs from international airports in the region and road travel costs within Botswana are estimated in this study. This implies a conservative yet realistic approach.

\subsubsection{Determination of travel costs for Botswana citizens and resident tourists}

To estimate the travel costs, it is important to know the origin of tourists in Botswana, but the data does not show the origin of the tourists. Despite this data deficiency, a very small percentage of tourists usually have Maun and the surrounding areas as their origin (Gojamang, personal communication 2004; Mbaiwa, personal communication 2004). Based on this fact, it is assumed that only 2 per cent of the visitors come from Maun and the surrounding areas, while the origins of 98 per cent of the visitors are the major urban centres and villages of Gaborone, Francistown, Lobatse, Selibe Pikwe, Sua town, Kasane, Orapa, Jwaneng, Ghantsi, Kang Serowe, Palapye, Ramotswa, Kanye and Mahalapye. In addition, it is assumed that all citizen and resident tourists travel by road from these places to Maun and to the Moremi game reserve. The distance between 
Maun and the Moremi game reserve is approximately $20 \mathrm{~km}$ of tarred road and $80 \mathrm{~km}$ of dirt road.

To estimate the cost of travel per kilometre, the government of Botswana's official rate for mileage cost is used. The official rates are $\mathrm{P} 2.90$ / $\mathrm{km}$ for dirt road, $\mathrm{P} 2.10 / \mathrm{km}$ for gravel road, and $\mathrm{P} 1.30 / \mathrm{km}$ for tarred road. Each vehicle is estimated to have a sitting capacity of 5 people. The number of vehicles is therefore determined by dividing the total number of tourists by the estimated sitting capacity of each vehicle (5 persons). Assuming that all vehicles function at full capacity all the time makes the figure a conservative assumption. Multiplying the total number of vehicles by the distance covered and the cost per kilometre thus arrives at an estimated figure for the cost of travel for citizen and resident tourists.

For the remaining 98 per cent of the resident and national visitors, it is assumed that they travel by road and covere an average distance of 698 kilometres between the 15 urban centres and Maun. Their cost of travel is estimated in the same way as that of the assumed 2 per cent who have Maun and the surrounding areas as their origin.

\subsubsection{Determination of travel cost for South African tourists}

Of the tourists who come from South Africa, it is assumed that about 95 per cent of them travel by road to Maun, while only 5 per cent use air transport (Gojamang, personal communication 2004). Those who travel by road enter through the boarder gates of Tlokweng, Martins Drift or Lobatse. The average distance between the three boarder gates and Maun is $925 \mathrm{~km}$. The cost of travel for this category of tourists is estimated in the same way as that for citizens.

For the 5 per cent of South African tourists who are assumed to use air transport, their travel cost is estimated by multiplying the cost of a return air ticket of $\mathrm{P} 2211.00$ between Maun and Johannesburg by the number of tourists.

\subsubsection{Determination of travel cost by other international tourists}

International tourists, categorised as foreign visitors from countries other than South Africa, use air transport from either Johannesburg in South Africa, Victoria Falls in Zimbabwe or Windhoek in Namibia. Data on air travel costs between Maun and Johannesburg, Maun and Windhoek, and Maun and Victoria Falls can be obtained from Air Botswana schedule of fares. The travel cost of this category of visitors is estimated by multiplying the average cost of a return air ticket of P2115.00 from each of the three departure points by the number of tourists. The cost of road transport for these three groups of tourists is then estimated in the same way as the cost for the other tourists who travel by road from Maun to Moremi game reserve.

\subsubsection{Determination of the values for accommodation and vehicle fees}

The cost of accommodation (camping) is calculated from the total number of people who spend nights in the park times the number of nights spent times the average camping fees per person per night. The camping fees are P5.00, P15.00 and P20.00 for citizens, residents and non-resident, respectively. Entry fees are P10.00, P20.00 and P30.00 for citizens, residents and non-resident, respectively. Other costs to tourists include vehicle, boat, aircraft and Parks and Reserve Reservation Office (PARRO).

Vehicle fees are determined based on the weight of a vehicle and whether the vehicle is registered in Botswana or not. The revenue from vehicles can be calculated from the number of vehicles per day times the charge according to vehicle weight. Vehicles registered in Botswana weighing under $3500 \mathrm{~kg}$, between 3500 and $7000 \mathrm{~kg}$ and over $7000 \mathrm{~kg}$, are charged P10.00, P500.00 and P800.00, respectively. Vehicles that are not registered in Botswana weighing under $3500 \mathrm{~kg}$, between 3500 and $7000 \mathrm{~kg}$ and over 7 000kg, are charged P50.00, P1 000.00 and P1 500.00, respectively.

\subsection{Non-use values held by tourists}

Data on the willingness of tourists to pay towards the preservation of the Okavango Delta was collected through a semi-structured questionnaire. Following the development of the 
questionnaire at the Okavango Research Centre in Maun, the questionnaire was pre-tested among 10 tourists in local hotels and then revised. In the actual survey, no systematic sampling was carried out because the aim was to get as many responses as possible. Some questionnaires were handed out by research assistants to tourists at various points of arrival (Maun Airport, hotels, lodges and various camping sites), while others were placed at the reception offices at various accommodation facilities. A total of 500 questionnaires were distributed. The purpose of the survey was explained fully to respondents in the covering letter, and the respondents were also assured that any information they supplied would be used only for academic purposes. Tourists were requested to either mail the completed questionnaire using an already addressed envelope, or to leave the questionnaire at the reception desks of the hotels, lodges and airport. The completed questionnaires were collected regularly from these points. A total of 132 questionnaires were returned which represented a response rate of 26.4 per cent. The low response rate is typical of mail survey approaches in contingent valuation studies. Although mail surveys are cheaper to administer, their disadvantage is that the researcher does not have the opportunity to provide more information for respondent when the need for clarification of issues arises. Further, the respondent is not obliged to return the questionnaire even if it has been adequately completed.

\subsubsection{The Contingent valuation scenario}

Tourists were presented with following scenario:

The Okavango River is increasingly being viewed as a source of water for development by the governments of Namibia, Botswana and Angola. In 1996 the Namibian government proposed to extract about 17 million cubic metres of water annually from the Okavango River. Hydrological simulations indicate that as a result of water extraction, the maximum loss of inundated area will be approximately 7.5 square kilometres. This loss is equivalent to 0.1 per cent of the total inundated area of the delta. Assume that the Permanent Okavango River
Basin Commission (OKACOM) wishes to establish an Okavango River Conservation fund (ORCOF) with the aim of supporting activities that will help conserve the Delta. Assume also that the funds will be used in the best possible way you can think of. Would you be willing to contribute to this fund as a one-time payment?

If tourists answer yes, they are asked to state how much they would be willing to pay towards the preservation of the Delta. Those unwilling to pay are asked to state their reasons.

\section{5}

\section{Results and discussion}

\subsection{Origin and numbers of tourists}

A total of 37376 tourists visited the Moremi game reserve in 2003. 29 per cent of the visitors were private visitors, 23 per cent were clients from mobile operators, 23 per cent were clients from fixed camps/lodges inside Moremi game reserve, and 25 per cent were visitors from fixed camps/lodges outside Moremi game reserve. According to category, the visitors can be grouped as citizens (4 282), residents (2 435), South Africans (6 114), residents of other African countries (615), North Americans (6 059), South Americans (532), residents of the United Kingdom (3 148), Europeans (12 529), Australians/New Zealanders (1 300), resident of Asian countries (281) and residents of other countries (81). Europeans constitute the highest percentage of visitors (33.5 per cent), while tourists from South Africa constitute the second highest percentage (16 per cent).

\subsection{Consumptive use values}

Table 1 shows the number of animals sold and killed and their associated values in the Okavango Delta. The values show the pattern of consumption of animal biomass in 2003. The estimated consumptive use value is estimated at P4 002250 (US\$816 659.1). On per hectare basis this value converts to P8.14/ha (US\$1.66/ ha). Allowing a 20 per cent margin of error, the estimated value lies between US\$653 327.28 and US\$979 990.94. 
Table 1

Consumptive use value of tourism during 2003

\begin{tabular}{|c|c|c|c|c|c|}
\hline Animal & $\begin{array}{c}\text { Citizen price } \\
\text { (Pula) }\end{array}$ & $\begin{array}{l}\text { Non-citizen } \\
\text { price (Pula) }\end{array}$ & $\begin{array}{c}\text { Number } \\
\text { sold }\end{array}$ & $\begin{array}{l}\text { Total value* } \\
\text { (Pula) }\end{array}$ & $\begin{array}{c}\text { Total value } \\
\text { (US\$) }\end{array}$ \\
\hline Baboon & 50 & 200 & 43 & 9000 & 1836.45 \\
\hline Buffalo & 150 & 5000 & 109 & 486500 & 99270.33 \\
\hline Duiker & 100 & 300 & 13 & 900 & 883.65 \\
\hline Elephant & 8000 & 20000 & 106 & 2112000 & 430953.60 \\
\hline Spotted hyena & 100 & 300 & 13 & 4200 & 857.01 \\
\hline Impala & 150 & 500 & 162 & 83950 & 17130.0 \\
\hline Kudu & 300 & 1000 & 108 & 91900 & 18752.20 \\
\hline Leopard & 1500 & 10000 & 23 & 230000 & 46931.5 \\
\hline Ostrich & 300 & 1000 & 28 & 25900 & 5284.90 \\
\hline Steenbok & 100 & 300 & 68 & 18800 & 3836.14 \\
\hline Tsessebe & 500 & 3000 & 110 & 328000 & 66928.4 \\
\hline Warthog & 150 & 500 & 105 & 54150 & 11049.31 \\
\hline Wildbeest & 500 & 2500 & 47 & 115500 & 23567.78 \\
\hline Lechwe & 300 & 1000 & 110 & 106600 & 21751.73 \\
\hline Zebra & 1000 & 5000 & 41 & 240000 & 48972.0 \\
\hline Eland & 700 & 2500 & 10 & 25000 & 5101.25 \\
\hline Crocodile & 300 & 1000 & 10 & 25900 & 5284.90 \\
\hline $\begin{array}{l}\text { Black-backed } \\
\text { jackal }\end{array}$ & 50 & 200 & 13 & 2600 & 530.53 \\
\hline Wild cat & 50 & 200 & 1 & 200 & 40.81 \\
\hline Porcupine & 50 & 200 & 2 & 600 & 122.43 \\
\hline Gemsbok & 700 & 2500 & 20 & 39200 & 7998.76 \\
\hline Vervet monkey & 50 & 200 & 1 & 200 & 40.81 \\
\hline Springbok & 150 & 400 & 6 & 1150 & 234.66 \\
\hline TOTAL & & & & 4002250 & 816659.1 \\
\hline
\end{tabular}

* Total value comprises values derived using both citizen and no citizen prices

\subsection{Non-consumptive use values of tourism}

\subsubsection{Road travel cost of tourists}

Table 2 shows the road travel costs for various tourists, calculated using the assumptions stated above. The total road travel costs for all tourists in 2003 are estimated at P9 042318 (US\$1
845 085). The highest travel costs are for South African tourists, who contributed 38 per cent of the value for road travel costs. This is because of Botswana's proximity to South Africa, which makes road transport much cheaper than air transport. Consequently, a large number of South Africans use vehicles as compared to air transport. 
Table 2

Road travel costs of tourists

\begin{tabular}{|c|c|c|c|c|c|c|c|}
\hline $\begin{array}{l}\text { Type of } \\
\text { tourists (1) }\end{array}$ & $\begin{array}{c}\text { Total } \\
\text { number of } \\
\text { tourists }(2)\end{array}$ & $\begin{array}{l}\text { Number of } \\
\text { tourists } \\
\text { based on } \\
\text { assumptions } \\
\text { (3) }\end{array}$ & $\begin{array}{c}\text { Number of } \\
\text { vehicles } \\
(4)=(3) / 5\end{array}$ & $\begin{array}{l}\text { Return } \\
\text { distance } \\
\text { travelled } \\
(\mathbf{k m})(5)\end{array}$ & $\begin{array}{c}\text { Rate used } \\
\text { (Pula/km) } \\
(6)\end{array}$ & $\begin{array}{c}\begin{array}{c}\text { Cost of } \\
\text { travel } \\
(\text { Pula })\end{array} \\
(7)=4 * 5 * 6\end{array}$ & $\begin{array}{c}\text { Cost of } \\
\text { travel (US\$) }\end{array}$ \\
\hline $\begin{array}{l}\text { Local } \\
\text { (Maun) }\end{array}$ & - & $\begin{array}{l}134 \\
134\end{array}$ & $\begin{array}{l}27 \\
27\end{array}$ & $\begin{array}{r}40 \\
160\end{array}$ & $\begin{array}{l}1.3^{\mathrm{a}} \\
2.9^{\mathrm{b}}\end{array}$ & $\begin{array}{r}1404 \\
12528\end{array}$ & $\begin{array}{r}286.49 \\
2556.34\end{array}$ \\
\hline $\begin{array}{l}\text { Residents \& } \\
\text { other local } \\
\text { tourists }\end{array}$ & 6717 & $\begin{array}{l}6583 \\
6583\end{array}$ & $\begin{array}{ll}1317 \\
1317\end{array}$ & $\begin{array}{r}1436 \\
160\end{array}$ & $\begin{array}{l}1.3 \\
2.9\end{array}$ & $\begin{array}{c}2458575.6 \\
611088\end{array}$ & $\begin{array}{ll}501 & 672.35 \\
124 & 692.51\end{array}$ \\
\hline $\begin{array}{l}\text { South } \\
\text { Africans }\end{array}$ & $\begin{array}{l}6114 \\
6114 \\
6114 \\
6114\end{array}$ & $\begin{array}{r}5808 \\
5808 \\
306 \\
306\end{array}$ & $\begin{array}{r}1162 \\
1162 \\
61 \\
61\end{array}$ & $\begin{array}{r}1890 \\
160 \\
40 \\
160\end{array}$ & $\begin{array}{l}1.3 \\
2.9 \\
1.3 \\
2.9\end{array}$ & $\begin{array}{rl}2855 & 034 \\
539 & 168 \\
3 & 172 \\
28 & 304\end{array}$ & $\begin{array}{rl}582 & 569.7 \\
110 & 617.23 \\
647.25 \\
5 & 775.43\end{array}$ \\
\hline $\begin{array}{l}\text { International } \\
\text { Overseas }\end{array}$ & $\begin{array}{l}24545 \\
24545\end{array}$ & $\begin{array}{r}24545 \\
24545\end{array}$ & $\begin{array}{l}4909 \\
4909\end{array}$ & $\begin{array}{r}40 \\
160\end{array}$ & $\begin{array}{l}1.3 \\
2.9\end{array}$ & $\begin{array}{r}255268 \\
2277776\end{array}$ & $\begin{array}{rr}52 & 087.44 \\
464 & 780.19\end{array}$ \\
\hline Total & & & & & & 9042318 & 1845085 \\
\hline
\end{tabular}

$\mathrm{a}=$ mileage rate for tarred road

$\mathrm{b}=$ mileage rate for dirt road

Source: own calculations based on Northern Parks and Reserves Visitor Statistics Annual Report, 2003.

\subsubsection{Air travel costs}

Air travel costs for South African tourist visitors in 2003 is estimated at P676 566 (US\$138 053.99), while those for international tourists is estimated at P51 912

675 (US\$10 592 781.33) (Table 3). The total air travel costs are therefore P52 589241 (US\$10 730 834.62), which is higher than that for road transport.

Table 3

Air travel costs of tourists

\begin{tabular}{|l|c|c|c|c|}
\hline Type of tourist & $\begin{array}{c}\text { Number of } \\
\text { tourists }\end{array}$ & $\begin{array}{c}\text { Cost of return } \\
\text { air ticket (Pula) }\end{array}$ & Travel cost (Pula) & Travel cost (US\$) \\
\hline South Africa & 306 & 2211 & 676566 & 138053.29 \\
\hline International & 24545 & 2115 & 51912675 & 10592781.33 \\
\hline Total & $\mathbf{2 4} \mathbf{8 5 1}$ & & $\mathbf{5 2 5 8 9 2 4 1}$ & $\mathbf{1 0 7 3 0 \mathbf { 8 3 4 . 6 2 }}$ \\
\hline
\end{tabular}

Source: compiled from Northern Parks and Reserves Visitor Statistics Annual Report (2003)

\subsubsection{Revenue generated from accommodation}

The revenue generated from accommodation in 2003 amounts to P539 774.50 (US\$110
140.99), while that from park entry, and vehicle, boat and aircraft fees is P6 482853.5 (\$US) (Table 4). Entry fees (78.26 per cent) contributed most to these revenues while boat fees contributed the least. 
Table 4

Revenue by type of fees

\begin{tabular}{|l|r|r|c|}
\hline Type of fee & $\begin{array}{c}\text { Revenue generated } \\
\text { (Pula) }\end{array}$ & $\begin{array}{c}\text { Revenue generated } \\
\text { (US\$) }\end{array}$ & \% contribution \\
\hline Entry & 5495723.50 & 1121402.38 & 78.26 \\
\hline Camping & 539774.50 & 110140.99 & 7.69 \\
\hline Vehicle & 488110.00 & 99598.85 & 0.95 \\
\hline Boat & 240.00 & 48.97 & 0.48 \\
\hline Aircraft & 34050.00 & 6947.90 & 7.62 \\
\hline PARRO & 464730.00 & 94828.16 & $\mathbf{1 0 0 . 0 0}$ \\
\hline Total & $\mathbf{7 ~ 0 2 2 ~ 6 2 8 . 0 0}$ & $\mathbf{1 4 3 2} \mathbf{9 6 7 . 0 0}$ & \\
\hline
\end{tabular}

Source: Northern Parks and Reserves Visitor Statistics Annual Report 2003

\subsubsection{Total direct non-consumptive use values of tourism}

Table 5 presents a summary of nonconsumptive use values of tourism. The total value is approximately $\mathrm{P} 68$ million or $\mathrm{UD} \$ 14$ million. Allowing for a 20 per cent margin of error to either side, the estimated range is between US $\$ 11,2$ and US $\$ 16,8$ million. This translates to a value between US\$22.81 and US\$34.21 per hectare or US\$299.85 and US\$ $\$ 454.77$ per visitor. The results clearly indicate that air travel costs constitute a significant part ( 77 per cent) of the estimated total value as compared to road travel (13.2 per cent), accommodation ( 0.8 per cent) and other costs ( 9 per cent).

Table 5

Total direct non-consumptive use value of tourism

\begin{tabular}{|l|c|c|}
\hline Item & Estimated value in Pula & Estimated value in US\$ \\
\hline Area (ha) & 491400 & 491400 \\
\hline No. of tourists & 37376 & 37376 \\
\hline Value of accommodation & 539774.50 & 110141.0 \\
\hline Cost of road travel & 9042318 & 10730834.6 \\
\hline Cost of air travel & 52589241.0 & 1322826.3 \\
\hline Other costs & 6482853.5 & 14008886.86 \\
\hline Total value non-consumptive use & 68654187.00 & 374.81 \\
\hline Expenditure per person & 1836.85 & 28.51 \\
\hline Value/ha & 139.71 & 145 \\
\hline
\end{tabular}

Source: own calculations based on Northern Parks and Reserves Visitor Statistics Annual Report (2003)

\subsection{Non-use values held by tourists}

An estimate of total non-use values for tourists is obtained by adding all the stated figures for willingness to pay for the preservation of the Delta. The figures are then converted to Pula or
US\$ using the prevailing exchange rate. The willingness to pay per person is estimated from the total willingness to pay for all the respondents/the number of respondents with a positive willingness to pay. 


\subsubsection{Tourists' willingness to pay towards the conservation of the Okavango Delta}

In the tourist sample survey, 44 (33.3 per cent) of the respondents were willing to pay towards the preservation of the Delta; 68 (51.5 per cent) were not willing to pay; and 20 (15.2 per cent) abstained. Respondents unwilling to pay indicate a 'no' response to the willingness to pay question and then gave their reason(s) for being unwilling to pay. Those who abstained did not respond to the willingness question, or give their reasons for not being willing to pay. Protest zeros occur when a respondent who has a positive willingness to pay for a good gives a zero value, possibly because he or she is rejecting the legitimacy of the scenario presented or due to strategic behaviour (Carson, 2000). For instance, some respondents may morally object to placing a price on the environment. The problem therefore in analysing protest bids is in separating or identifying bids which are a true reflection of respondents' preferences from those that result from strategic behaviour. According to Jorgensen et al. (1999), protest responses should routinely be removed from contingent valuation samples because it is assumed that they are not indicative of respondents' true opinions about value. In a study measuring the benefits of water quality improvement in Massachusetts, Kaoru (1993) finds no significant bias in the estimation of respondents' willingness to pay after excluding protests as well as missing value. Therefore this study excludes protest values in the estimation of tourists' willingness to pay towards the preservation of the Delta.
Considering only those respondents willing to pay in the sample, the total willingness to pay is estimated at P46 163.34 (US\$9 419.63). The willingness to pay per person is estimated at P1 049.17 (US $\$ 214.08$ ). The reasons stated by those unwilling to pay are responses such as: 'I am already contributing to other conservation organisations'; 'The Okavango Delta should not be disturbed so that there should be no need to finance its conservation'; 'I have insufficient funds to contribute to the conservation of the Okavango Delta'; 'The Okavango Delta should generate its own funds through tourism for its conservation'; 'Even if I can contribute towards the conservation of the Okavango Delta, it is unlikely that the contribution will be channelled to the conservation of the Okavango Delta'; 'The conservation of the Okavango Delta should be the responsibility of the Botswana government'; 'The conservation of the Okavango delta should be the responsibility of international conservation organizations'; 'There are more international pressing issues than the conservation of the Okavango Delta.'

Using the proportion of respondents willing to pay (33 per cent) and the willingness to pay per person, and extrapolating to the total number of tourists (37 376) who visited Moremi game reserve in 2003 (Northern Parks and Game Reserve Statistics 2003), the total willingness to pay towards the preservation of the Okavango Delta is estimated at P12 940 462.78 (US\$2 640 501.43) (Table 6). On per hectare basis, this value converts to P26.33/ha (US\$4.76/ha). Assuming a standard deviation of 20 per cent on either side, the total willingness to pay lies between US\$56.52 and US\$84.78 per person.

\section{Table 6}

Tourists' total willingness to pay for the preservation of the Delta

\begin{tabular}{|l|c|}
\hline Item & Value \\
\hline Area (ha) & 491400 \\
\hline Total number of individuals & 37376 \\
\hline No. of tourists WTP & 12334 \\
\hline Total WTP (Pula) & 12940462.78 \\
\hline Total WTP (US\$) & 2640501.43 \\
\hline
\end{tabular}




\begin{tabular}{|l|c|}
\hline WTP /person (Pula) & 1049.17 \\
\hline WTP/person (US\$) & 214.08 \\
\hline WTP/ha (Pula) & 26.33 \\
\hline WTP/ha (US\$) & 4.76 \\
\hline
\end{tabular}

Source: own calculations based on tourist survey conducted by author in 2003

\section{6 Conclusions}

The direct consumptive use value of tourism in the Okavango Delta in 2003 is estimated at between US\$1.33/ha and US\$1.99/ha. Much higher direct values could raise concerns for ecological sustainability, especially when the rate of extraction (hunting) exceeds the rate of growth. However, the number of wildlife species to be hunted is based on adequate information on the size of the standing stock at the time when a hunting quota is allocated. The source of this information is annual wildlife aerial counts.

Direct non-consumptive use value of tourism in the Moremi game reserve in 2003, which includes the cost of air and road travel, is estimated at between US $\$ 11,2$ and US $\$ 16,8$ million. The aggregate cost per visitor is estimated to be between US\$299.85 and US\$454.77. The total value of non-consumptive use of tourism should be considered an underestimate because the tourists' cost of air travel outside Botswana is not included in the analysis and the conservative road transport assumptions. According to Republic of Botswana (1999), payment for tourist services such as airfares, which are attributable to Botswana, are paid outside Botswana. This makes it difficult to evaluate the tourism impact to the whole economy. Despite this problem, the value of direct non-consumptive use of tourism can be compared to other land use. The value of direct non-consumptive use of tourism in 2003 was more than the gross value of commercial fishing in the Delta in that year, estimated at P1 108800 (US\$226 250.84) (see Mmopelwa et al., 2005). Both tourism and commercial fishing can be pursued together in the interests of economic diversification.
The value is also higher than the aggregate recreational value of Lake Nakuru National Park in Kenya (Navrud \& Mungatana, 1994). The Lake's aggregate recreational value for nonresident and residents visitors is estimated at US\$13.7-US $\$ 15.1$ million, while those for nonresident visitors and residents is estimated at US\$10.1-US\$10.6 million and US\$3.6US $\$ 4.5$ million, respectively.

The per hectare use value of non-consumptive tourism calculated for 2003 is about 97 times the private use value of cattle under communal grazing in Botswana for that year (see Arntzen, 1998), indicating that tourism has a higher per hectare yield than the livestock sector. Compared to other recreational areas in other countries, the value per hectare from this study is smaller than for Lake Nakuru National Park (US\$76.1-US\$83.9/ha) and that of the Rooibos Bushveld area of Kruger National Park in South Africa (US\$96.66/ha) (see Blignaut \& Moolman, 2004), but compares well with that of the Olango Islands in the Philippines (US\$40-US\$50) (see White, Ross \& Flores, 2000).

The existence value of the Okavango Delta, as estimated from the willingness of tourists to pay towards its conservation, is estimated at between US\$2,1 and US\$3,2 million, with the mean sum that tourists are willing to pay US $\$ 214.08$ per person. The existence value represents the monetary sacrifices that tourists are prepared to make to ensure that the Delta remains relatively undisturbed. This value is not the 'maximum or minimum' existence value of the Okavango Delta, mostly because other people elsewhere who are aware of the existence of the Delta also assign an existence value to the Delta. A mean value for the total population could be estimated. 
Despite the apparent difficulty of determining the existence value of the Delta, should the Delta be preserved for the sake of its own existence, this will provide other tangible benefits, such as wildlife viewing, which are commonly recognised by decision makers. Though difficult to determine, and sometimes very difficult to conceptualise, the existence value of resources such as the Delta is a very useful figure that should be brought to the attention of policy makers and environmental conservationists.

\section{References}

1 ARNTZEN, J. (1998) "Economic valuation of communal rangelands in Botswana: A case study", CREED Working Paper Series, no. 17. International Institute for Environment and Development: London.

2 ASHTON, P.J.; NORDIN, L. \& ALONSO, L.E. (2003) "Chapter 1: Introduction to the Okavango Delta and the AquaRap Expedition: A rapid biological assessment of the aquatic ecosystems of the Okavango Delta, Botswana: High water survey, RAP Bulletin of Biological Assessment No. 27 ", In Alonso, L.E. \& Nordin, L. (eds.) Conservation International: Washington.

3 BARBIER, E.B.; ACREMAN, M. \& KNOWER, D. (1997) Economic Valuation of Wetlands: Guide for Policy and Planners, Ramsar Convention Bureau: Gland.

4 BARNES, J.I. (1998) "Wildlife economics. A study of direct use values in Botswana's wildlife sector", PhD Thesis, University of London; London.

5 BARNES, J.I.; CANNON, J. \& MORRISON, K. (2001) "Economic returns to selected land uses in Ngamiland, Botswana", Conservation International: Maun.

6 BARNES, J.I.; SCHIER, C. \& VAN ROOY, G. (1997) "Tourists willingness to pay for wildlife viewing and conservation in Namibia", Directorate of Environmental Affairs. Research Discussion, Paper No. 15, (unpublished paper).

7 BATEMAN, I.J. \& LANFORD, I. H. (1997) "Non-users' willingness to pay for a national park: An application and critique of the contingent valuation method", Regional Studies, 31: 571582.

8 BATEMAN, I.J.; CARSON, R.T.; DAY, B.; HANEMANN, M.; HETT, T.; JONES-LEE, M.; LOOMES, G.; MOURATO, S.; OZDEMIROGLO, E.; PEARCE, D.W.;
SUGDEN, R. \& SWANSOON, J. (2002) Economic Valuation with Stated Preference Techniques: A Manual, Edward Elgar: Cheltenham.

9 BLIGNAUT, J.N. \& MOOLMAN, C.E. (2004), "Conservation as an alternative land use option towards poverty alleviation: A case study from South Africa", Paper presented at the Restoring Natural Capital Conference, Port Alfred, 16 September.

10 BLOMQUIST, G.C. \& WHITEHEAD, J.C. (1998) "Resource quality information and validity of willingness to pay in contingent valuation", Resource and Energy Economics, 20(2): 179-196

11 CARSON, R.T. (2000) "Contingent valuation: A user's guide”, Environmental Science and Technology, 34(8): 1413-1418.

12 CHOPRA, K. (1993) "The value of non-timber forest products: An estimation for tropical deciduous forest in India”, Economic Botany, 47(30): 251-257.

13 FOLMER, H.; GABEL, H.L. \& OPSCHOOR, H. (1997) Principles of environmental and resource economics, Edward Elgar: London.

14 GUMBRICHT, T.; WOLSKI, P.; FROST, P. \& MCCARTHY, T.S. (2004) "Forecasting the spatial extent of the annual flood in the Okavango Delta, Botswana", Journal of Hydrology, 290:178-191.

15 HANLEY, N. \& SPLASH, C.N. (1993) Cost Benefit Analysis and the Environment, Edward Elgar: London.

16 HOWARTH, R. \& FABER, S. (2002) "Accounting for the value of ecosystem services", Ecological Economics, 41: 421-429.

17 ISANGKURA, A. (2000) Environmental Valuation: An Entrance Fee System for National Parks in Thailand, International Development Research Centre: Ottawa.

18 JORGENSEN, B.S.; SYME, G.J.; BISHOP, B.J. \& NAUCARROW, B.E. (1999) "Protest response in contingent valuation", Environmental and Resource Economics, 14: 131-150.

19 KAHN, J.R. (1997) The Economic Approach to Environmental and Natural Resource, Harcourt Brace College Publishers: New York.

20 KAORU, Y. (1993) "Differentiating use and non-use values for coastal pond water quality improvement”, Environmental and Resource Economics, 3(5): 487-494.

21 KRUG, W.; SUICH, H. \& HAIMBODI, N. (2002) "Park pricing and economic efficiency in Namibia." Directorate of Environmental Affairs 
Research Discussion Paper No. 45 (unpublished paper).

22 LOOMIS, J.M.; KENT, P.; STRANGE, L.; FAUSCH, K. \& COVICH, A. (2000) "Measuring the total economic value of restoring ecosystem services in an impaired river basin: Results from a contingent valuation survey", Ecological Economics, 33: 103-117.

23 MASUNDIRE, H.; RINGROSE, S.; SEFE, F.T.K. \& VAN DER POST, C. (1998) Botswana Wetlands Policy and Strategy: Inventory of Wetlands of Botswana, National Conservation Strategy Agency, Ministry of Local Government, Lands and Housing: Gaborone.

24 MATHIEU, L.; LANGFORD, A.H. \& KENYON, W. (2003) "Valuing marine parks in a developing country: A case study of the Seychelles", Environment and Development Economics, 8(2): 373-390.

25 MBAIWA, J.E. (2002) "The socio-economic and environmental impacts of tourism development on the Okavango Delta, north western Botswana", Journal of Arid Environment, available online at: http://www.idealibrary.com. (Accessed on 15 February 2006).

26 MBAIWA J.E. (2005) "Enclave tourism and its socio economic impacts in the Okavango Delta, Botswana”, Tourism Management, 26: 157-172.

27 MMOPELWA, G.; SEGAMETSE, R. \& MOSEPELE, K. (2005a) "Cost benefit analysis of commercial fishing in Shakawe, Ngamiland, Botswana”, Botswana Notes and Records, 37: 11-19

28 MMOPELWA, G.; KGATHI, D.L.; MASAMBA, W.R.L \& THUKUZA A. (2005b) "Willingness to pay for reliability of water supply and quality in Maun, Botswana: An Application of the Contingent Valuation Method". Botswana Notes and Records, 37: 97-107.

29 MONNA, S.C. (1999) A Framework for International Cooperation for the Management of the Okavango Basin and Delta, Ramsar COP7 DOC.205, The Ramsar Convention on Wetlands. http://www.ramsar.org/cop7doc20.5etm. (Accessed 19 November 2002).

30 MUNASINGHE, M. (1992) "Environmental economics and valuation in development decision making”, Environment Working Paper No. 51, The World Bank: Washington.

31 NAVRUUD, S. \& MUNGATANA, E.D. (1994)

"Environmental valuation in developing countries: The recreation value of wildlife viewing", Ecological Economics, 11(2): 135-151.
32 NORTHERN PARKS AND GAME RESERVE STATISTICS (2003). Department of Wildlife and National Parks, Ministry of Environment, Wildlife and Tourism: Maun.

33 OGLETHORPE, D.R. \& MILIADOU, D. (2000) "Economic valuation of the non-use attributes of a wetland: A case-study for the Lake Kirkini”, Journal of Environmental Planning and Management, 43(6): 755-767.

34 PATE, J. \& LOOMIS, J. (1997) "The effect of distance on the willingness to pay values: A case study of wetlands and Salmom in California”, Ecological Economics, 20(3): 199-207.

35 PEARCE, D. \& MORAN, D. (1994) The Economic Value of Biodiversity, Earthscan Publication: London.

36 PEARCE, D.W. \& TURNER, R.K. (1990) Economics of natural resources and the environment, Harvester Wheatsheaf: New York.

37 PERMAN, R.; MA, Y.; MCGILVRAY, J. \& COMMON, M. (2003) Natural Resource and Environmental Economics, Pearson Addison Wesley: Harlow.

38 PRATO, T. (1998) Natural resource and environmental economics. Iowa State University Press: Iowa.

39 REPUBLIC OF BOTSWANA (1999) An Assessment of the Economic Impact of Tourism in Botswana: Botswana Tourism Development Programme Project No.7 ACP. BT. 4/No. 6 ACP BT 44 , Ministry of Commerce and Industry: Gaborone.

40 REPUBLIC OF BOTSWANA. (2003) National Development Plan 2003/04-2008/09: Ministry of Finance and Development Planning. Government Printer: Gaborone.

41 REPUBLIC OF BOTSWANA. (2004) Annual Economic Review: Ministry of Finance and Development Planning, Government Printer: Gaborone.

42 ROTHERT, S. (1997) "Which way the Okavango Delta?” In Mongae, F. (ed.) Proceedings of a National Conference on Conservation and Management of Wildlife in Botswana: Strategies for the Twenty First Century, $13^{\text {th }}-17^{\text {th }}$ October, Department of Wildlife and National Parks and Kalahari Conservation Society: Gaborone.

43 SEENPRACWONG, U. (2000) An Economic Analysis of the Coral reefs in the Andaman Sea of Thailand, International Development Research Centre: Ottawa.

44 SILVIS, M.J., ONEKA, M. \& VERHAGEN, A. (2000) "Wetlands: Lifeline for the people at the edge", Physics, Chemistry and Earth, 25(7-8): 645-652. 
45 SUTHERLAND, R.J. \& WALSH, R.G. (1985) "Effect of distance on preservation of value of water quality", Land Economics, 61(3): 281-291.

46 TERRY, M.E. (1999) "The economic and social significance of the handicraft industry in Botswana”, PhD Thesis, School of Oriental and African Studies, University of London: London.

47 TIETENBERG, T. (2000) Environmental and Natural Resource Economics, Addison-Wesley Longman: Reading.

48 TURNER, R.K.; PEARCE, D. \& BATEMAN, I. (1994) Environmental Economics: An Elementary Introduction, Harvester Wheatsheaf: New York.

49 TURNER, R.K.; JEROEN, C.J.M.; BERG, V.D.; SODERRQVIST, T.; BARENDREGT, A.; STRATEN, J.V.D.; MALTBY, E. \& VAN IRELAND, E.K. (2000) "Ecological economic analysis of wetlands: Scientific integration for management and policy", Ecological Economics, 35 (1):7-23.
50 TURPIE, J. (2004) "The role of resource economics in the control of invasive alien plants in South Africa", South African Journal of Science, 100: 87-93.

51 TURPIE, J.K.; HEYDENRYCH, B.J. \& LAMBERTH, S.J. (2003) "Economic value of terrestrial and marine biodiversity in the Cape Floristic Region: Implications for defining effective and socially optimal conservation strategies”, Biological Conservation, 112: 233251.

52 VENKATACHALAM, L. (2004) "The contingent valuation method: A review", Environmental Impact Assessment Review, 24: 89-124.

53 WHITE, A.T., ROSS, M. \& FLORES, M. (2000) "Benefits and costs of coral reef in Olango Islands, Philippines", In CESAR, H.J.S. (ed.) Collected Essays on the Economics of Coral Reefs, http://www.reefbase.org/pdf/cesar_2000/ cesar_18.pdf. (Accessed 15 October 2004). 